\title{
PENGEMBANGAN PEMBELAJARAN E-LEARNING DENGAN WEB LOG SEBAGAI ALTERNATIF BAHAN AJAR GURU
}

\author{
Irnin Agustina Dwi Astuti ${ }^{1}$, Nurullaeli ${ }^{2}$, Alpi Mahisha Nugraha ${ }^{3}$ \\ ${ }^{1,2,3}$ Fakultas Teknik, Matematika, dan IPA \\ Universitas Indraprasta PGRI \\ Email: irnin.agustina@gmail.com
}

\begin{abstract}
The purpose of this public service activities is to enhance the role of vocational teachers and vocational Respati 1 Respati 2 in developing innovative learning media. Innovation learning media in the form of web logs. Log web presence is expected to be maximized by teachers as an alternative medium of knowledge transmission, media on-line learning, as well as solutions to the problem of lack of conventional instructional hours in class. Web logs can be accessed by students and teachers anywhere and anytime, which is expected to motivate students to learn independently grasp the concepts of the lessons. This learning innovations make the learning process more flexible and efficient. The method in this devotion in the form of training methods, mentoring and discussion. Training is done by giving seminars creating web log and web log manufacturing practices teaching materials by teachers was held on December 15-16, 2016. The results of the training in the form of web logs each participant that can be used for the learning process. Outcomes in community service activities in the form of modules making web log.
\end{abstract}

Keywords: e-learning, web log, teaching materials.

\begin{abstract}
Abstrak.Tujuan kegiatan pengabdian kepada masyarakat ini yaitu untuk meningkatkan peran guru SMK Respati 1 dan SMK Respati 2 dalam mengembangkan inovasi media pembelajaran. Inovasi media pembelajaran berupa web log. Keberadaan web log diharapkan dapat dimaksimalkan oleh para guru sebagai media alternatif penyampaian pengetahuan, media pembelajaran on-line, serta solusi untuk masalah kurangnya jam pembelajaran konvensional di kelas. Web log tersebut dapat diakses oleh siswa dan guru dimana pun dan kapan pun, sehingga diharapkan dapat memotivasi siswa untuk belajar mandiri memahami konsep-konsep pelajaran. Inovasi pembelajaran ini membuat proses pembelajaran lebih fleksibel dan efisien. Metode dalam pengabdian ini berupa metode pelatihan, pendampingan, dan diskusi. Pelatihan dilakukan dengan cara memberikan seminar pembuatan web log dan praktik pembuatan web log bahan ajar oleh guru yang dilaksanakan pada tanggal 15-16 desember 2016. Hasil pelatihan berupa web log masing-masing peserta yang dapat digunakan untuk proses pembelajaran. Luaran dalam kegiatan pengabdian masyarakat ini berupa modul pembuatan web log.
\end{abstract}

Kata Kunci: e-learning, web log, bahan ajar.

\section{PENDAHULUAN}

Pada zaman modern seperti sekarang ini, kemajuan teknologi di bidang informasi dan komunikasi terus meningkat. Saat ini semua orang dapat memperoleh segala informasi hanya dengan mengakses internet. Terlebih lagi, perkembangan internet diimbangi dengan perkembangan perangkat keras atau pun perangkat lunak serta banyak nya aplikasi yang bertujuan untuk memudahkan pekerjaan seharihari baik di bidang pendidikan, perkantoran, dan lainnya (Kristiyanti, 2010:1-2).

Di bidang pendidikan, media internet sering kali digunakan sebagai media pembelajaran yakni alat bantu untuk memperagakan fakta, konsep, prinsip atau prosedur tertentu agar tampak lebih nyata atau konkrit (Sujoko, 2013:1). Hal ini bertujuan untuk memberikan pengalaman lebih konkrit, memotivasi serta meningkatkan daya serap dan daya ingat siswa dalam balajar.

Hasil wawancara dengan salah satu guru IPA SMK Respati 1 Jakarta Timur menunjukkan bahwa minat belajar mandiri siswa di sekolah tersebut sangat kurang. Hal itu disebabkan rendahnya minat baca dan kurangnya inovasi media pembelajaran yang tepat. Penggunakan internet sebagai inovasi media pembelajaran mempunyai keunggulan, yaitu siswa dan guru dapat mengakses informasi dimana pun dan 
kapan pun. Pada saat ini, banyak siswa yang memanfaatkan internet untuk mencari materimateri yang dianggap kurang dimengerti saat dijelaskan di sekolah. Bahkan tidak sedikit siswa yang menggunakan informasi dari internet untuk menyelesaikan tugas. Fenomena seperti ini sudah tidak asing di perkotaan. Melihat pengguna internet di kalangan siswa khususnya Sekolah Menengah Atas (SMA) atau sederajat mencapai 64.7\% (APJII, 2015:12).

Pelaksanaan prinsip penyelenggaraan pendidikan dengan menggunakan internet sebagai media pembelajaran tentu saja tidak bertentangan dengan tujuan pendidikan nasional yang tercantum dalam UU RI No 20 Tahun 2003 tentang Sistem Pendidikan Nasional Bab II pasal 3, yaitu mengembangkan kemampuan dan membentuk watak serta peradaban bangsa yang bermartabat dalam rangka mencerdaskan kehidupan bangsa. Namun dalam penggunaan internet oleh siswa, tak sedikit siswa yang mengalami masalah seperti kesulitan memperoleh informasi yang akurat. Selain itu, media internet yang bebas memungkinkan siswa dapat mengakses konten-konten yang membuat siswa menjadi tidak bermartabat. Kejadian seperti itulah yang tidak diharapkan selama penggunaan internet oleh siswa. Oleh karena itu, sudah seharusnya para tenaga pendidik seperti para guru untuk mengontrol informasi-informasi yang akan diakses oleh siswa dalam mencari materi tambahan.

Manfaat penggunaan media pembelajaran berbasis teknologi informasi seperti internet, yaitu: 1) meningkatkan dan mengembangkan keilmuan guru dan siswa khususnya dalam berkreasi dan berinovasi, 2) meningkatkan kreatifitas, keuletan, dan kemampuan siswa, 3) media untuk mendapatkan metode pembelajaran yang sesuai dengan keinginan siswa, sehingga siswa dapat lebih menyukai pembelajaran, 4) cara untuk mengatasi keterbatasan media pembelajaran yang belum tersedia di sekolah, 5) cara untuk mengatasi kejenuhan siswa disekolah karena media pembelajaran yang monoton, 6) memungkinkan adanya perubahan paradigma pendidikan yang lebih baik (Suprapto, 2006: 3-4).

Pembelajaran menggunakan internet yang dimaksud adalah dengan cara mengakses website atau web log yang menunjang pembelajaran. Tentu saja, web log tersebut memiliki sifat interaktif, sebagai media massa dan gudang informasi. Pembelajaran berbasis internet menyediakan lebih dari sekedar akses. Pembelajaran berbasis internet yang bermutu memberikan informasi yang jauh lebih baik dari pembelajaran tradisional. Dengan menggunakan internet kita dapat menggabungkan informasi yang lebih luas (Jas, 2012:1-2). Saat ini sudah tersedia banyak sekali website dan web log (blog) jika kita mengakses internet. Website dan web $\log$ untuk saat ini seperti perpustakaan terbesar di dunia, karena dapat berfungsi sebagai sumber belajar dan sekaligus media pembelajaran bagi siswa. Namun seringkali siswa menemukan masalah selama mengakses website atau web log.

Produk yang diharapkan dalam kegiatan pengabdian kepada masyarakat ini berupa web log mengenai mata pelajaran di sekolah dengan konten yang menarik dan berkualitas. Guru dapat mengemas bahan ajar ke dalam web log yang dapat diakses dimana pun dan kapan pun, sehingga diharapkan dapat memotivasi siswa untuk belajar mandiri memahami konsep-konsep pelajaran. Sedangkan luaran kegiatan pengabdian kepada masyarakat dalam bentuk modul pembelajaran e-learning dengan web log yang dapat digunakan oleh guru ataupun pendidik.

\section{METODE PELAKSANAAN}

Pengabdian kepada masyarakat ini dilaksanakan di SMK Respati 1, yang beralamat di Jl. Inpres, kelurahan Tengah, Kramat Jati, Jakarta Timur pada tanggal 15-16 Desember 2016.

Peserta yang mengikuti pelatihan pembuatan web log ini berasal dari guru SMK 1 Respati dan SMK 2 Respati berlatar belakang mata pelajaran yang berbeda-beda sejumlah 20 peserta pelatihan.

Metode yang digunakan berupa metode pelatihan, pendampingan, dan diskusi. Pelatihan dilakukan dengan cara memberikan seminar pembuatan web log, kemudian dilanjutkan praktik pembuatan web log bahan ajar oleh guru dengan disertai modul pelatihan untuk mempermudah peserta dalam mengikuti pelatihan tersebut.

Tahapan kegiatan pengabdian kepada masyarakat, yaitu: 1) Tahap Pertama, yaitu tahap persiapan. Tim pelaksana melakukan kunjungan ke mitra terlebih dahulu untuk melakukan analisis mengenai kondisi mitra, peserta yang 
yang akan diberi pelatihan, dan menyusun rancangan kegiatan yang akan dilakukan; 2) Tahap kedua, yaitu tahap pelaksanaan. Tim pelaksana mengadakan pelatihan web log dan cara penyampaian materi secara lebih menarik kepada guru di lingkungan mitra. Setelah dilakukan pelatihan, guru membuat web log bahan ajar yang dapat diakses siswa untuk belajar mandiri; dan 3) Tahap ketiga, yaitu tahap evaluasi. Evaluasi terhadap proses selama tahap persiapan sampai pelaksanaan pengabdian kepada masyarakat. Tahap evaluasi ini meliputi evaluasi antusias peserta, keluaran yang berupa web log bahan ajar guru, dan saran atau kritik dalam pelaksanaan kegiatan pelatihan.

Tahap persiapan:

Survey lokasi dan menyusun rancangan kegiatan

Tahap pelaksanaan pelatihan pembuatan web log bahan ajar guru

Tahap Evaluasi

Gambar 1.Diagram Alur Kegiatan Pengabdian kepada Masyarakat.

\section{HASIL DAN PEMBAHASAN}

Program pengabdian kepada masyarakat dilaksanakan pada tanggal 15-16 Desember 2016 di SMK Respati 1 Jl. Inpres, kelurahan Tengah, Kramat Jati, Jakarta Timur. Program pengabdian ini dilakukan untuk melatih guru SMK Respati 1 dan SMK Respati2 dalam membuat bahan ajar guru menggunakan web log. Bahan ajar guru yang kreatif dan inovatif digunakan untuk memotivasi siswa belajar mandiri. Pengabdian kepada masyarakat ini selain dilaksanakan oleh tim yang terdiri dari dosen, juga dibantu oleh salah satu alumni Pendidikan Fisika Universitas Indraprasta PGRI.

Kegiatan pengabdian ini dibagi menjadi tiga tahap. Tahap pertama, yaitu persiapan. Pada tahap ini, tim melaksanakan survei pendahuluan untuk mengetahui situsi dan kondisi di SMK Respati 1 dan SMK respati 2. Setelah mendapatkan perizinan dari pihak sekolah, tim melaksanakan observasi lanjutan untuk lebih mengetahui kondisi guru yang akan diberi pelatihan. Berdasarkan observasi didapatkan hasil bahwa KBM di SMK Respati 1 dan SMK Respati 2 masih menggunakan papan tulis dan beberapa menggunakan PPT. Hal ini terjadi karena kurangnya pelatihan teknologi untuk inovasi media pembelajaran dan beberapa guru belum terlalu mahir dalam penggunaan internet untuk penyajian bahan ajar. Tahap persiapan selanjutnya tim menyiapkan rancangan kegiatan, bahan ajar, sarana, dan prasarana yang dibutuhkan dalam kegiatan pengabdian kepada masyarakat.

Tahap kedua, yaitu pelaksanaan. Pada tahap ini dilakukan pelatihan pembuatan bahan ajar guru berbasis web log. Kegiatan pelatihan diawali dengan penjelasan mengenai pentingnya inovasi media pembelajaran dan pemanfaatan web $\log$ sebagai inovasi penyajian bahan ajar guru. 


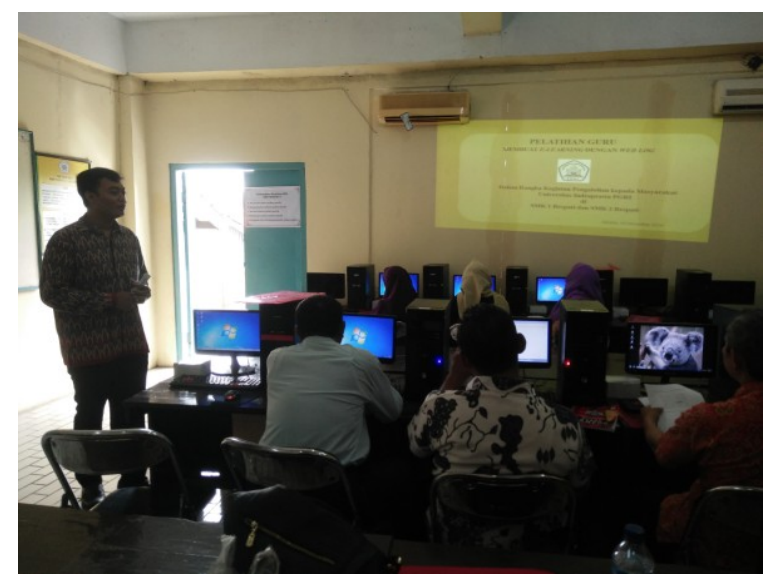

Gambar 2.Sosialisasi e-learning dengan web log.

Kemudian, peserta secara langsung mencoba membuat bahan ajar sesuai mata pelajaran yang diampu dengan web log. Peserta terlihat antusias dalam pelatihan ini, karena

menurut peserta web log adalah ilmu baru yang belum pernah mereka pelajari dan setelah mempraktikkan terlihat bahan ajar yang mereka buat lebih menarik.

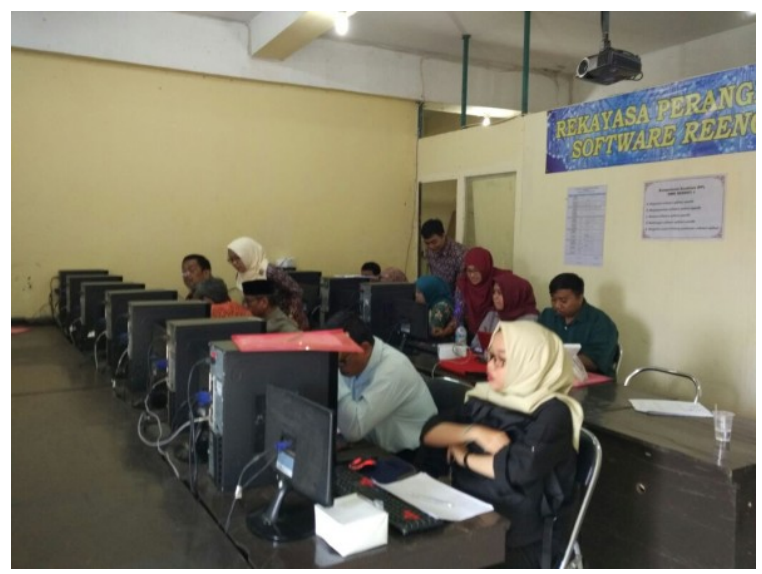

Gambar 3.Kegiatan pelatihan e-learning dengan web log.

Tahap ketiga, yaitu evaluasi. Tim pelaksana mengevaluasi seluruh kegiatan yang telah dilakukan. Pertama evaluasi pada web log yang dibuat oleh peserta. Secara keseluruhan peserta dapat membuat web log, hanya ada kendala kecil di awal berupa gangguan koneksi internet dan ada beberapa peserta yang belum mempunyai alamat email. Kendala tersebut tidak membutuhkan waktu yang lama untuk diatasi, setelah pihak sekolah yang berwenang dalam koneksi internet datang dan yang belum mempunyai alamat email dibuatkan alamat oleh tim.

\section{SIMPULAN DAN SARAN Simpulan}

Berdasarkan evaluasi yang dilakukan, secara umum pelaksanaan pengabdian masyarakat di SMK Respati 1 dan SMK Respati 2 berjalan dengan baik.Guru-guru antusias mengikuti acara pelatihan media pembelajaran berbasis web log. Guru antusias dalam pelatihan karena dapat menambah ilmu dalam mengembangkan inovasi media pembelajaran. Produk yang dihasilkan berupa web log bahan ajar guru yang dapat digunakan untuk proses KMB di kelas dan di luar kelas. Luaran dari kegiatan pengabdian masyarakat ini dalam bentuk modul pembuatan media pembelajaran berbasis web log yang dapat digunakan untuk tenaga pengajar dan masyarakat umum.

\section{Saran}

Untuk kemajuan KBM di SMK Respati 1 dan SMK Respati 2 pada khususnya dan Indonesia pada umumnya, saran tim pelaksana antara lain: 1) Guru lebih kreatif dan inovatif dalam menyajikan bahan ajar untuk memotivasi siswa belajar di kelas ataupun belajar mandiri di 
rumah; dan 2)Guru dapat memanfaatkan teknologi dalam proses KBM.

\section{UCAPAN TERIMAKASIH}

Penulis mengucapkan terimakasih kepada 1) Lembaga Penelitian dan Pengabdian Kepada Masyarakat UNINDRA yang telah memfasilitasi dan memberikan dana untuk kegiatan program Abdimas, dan 2) Kepala Sekolah SMK Respati 1 dan SMK Respati 2 yang telah memberikan ijin dan kesempatan untuk melaksanakan kegiatan pengabdian kepada masyarakat.

\section{DAFTAR PUSTAKA}

APJII. 2015. Profil Pengguna Internet Indonesia 2014. Jakarta: Asosiasi Penyelenggara Jasa Internet Indonesia.

Kristiyanti, M. 2010. Internet Sebagai Media Pembelajaran Yang Efektif. Majalah Ilmiah INFORMATIKA, Vol. 1 No. 1.
Jas, I, dkk. 2012. Penggunaan Media Pembelajaran Berbasis Website dalam Pembelajaran Matematika. Jurnal Pendidikan Matematika, Vol. 1, No. 1. Part $2: 1-5$.

Sari, R. A, dkk. 2014. Pengembangan Modul Pembelajaran Kimia Berbasis Blog untuk MAteri Struktur Atom dan Sistem Periodik Unsur SMA Kelas XI. Jurnal Pendidikan Kimia (JPK), Vol. 3, No. 2.

Sujoko. 2013. Pemanfaatan Teknologi Informasi dan Komunikasi sebagai Media Pembelajaran di SMP Negeri 1 Geger Madiun. Jurnal Kebijakan dan Pengembangan Pendidikan, Vol. 1, No. 1:71-77.

Suprapto. 2006. Peningkatan Kualitas Pendidikan Melalui Media Pembelajaran Menggunkan Teknologi Informasi di Sekolah. Jurnal Ekonomi \& Pendidikan, Vol. 3, No. 1. 